\title{
Correction: LncRNA HCP5A promotes follicular thyroid carcinoma progression via miRNAs sponge
}

Leilei Liang ${ }^{1}$, Jingchao Xu', Meng Wang ${ }^{1}$, Gaoran Xu', Ning Zhang ${ }^{1}$, Guangzhi Wang ${ }^{1}$ and Yongfu Zhao ${ }^{1}$

\section{Correction to: Cell Death \& Disease \\ https://doi.org/10.1038/s41419-018-0382-7 \\ Published online 07 March 2018}

After publication of this article, it came to our attention that there was an error in Fig. 3a wherein the migration panel of pcDNA3.3 was replicated in the invasion panel for HCP5. The correct image for the invasion panel of HCP5 is provided in the corrected Fig. 3a below. This error did not impact the conclusions of the article. We apologize for any inconvenience this may have caused.

This has been corrected in both the PDF and HTML versions of the Article.

Published online: 03 September 2019

Correspondence: Guangzhi Wang (wangguangzhi1986@hotmail.com) or Yongfu Zhao (zyf0386@sina.com)

'Department of General Surgery, The Second Hospital of Dalian Medical

University, Dalian, China

These authors contributed equally: Leilei Liang, Jingchao Xu

Edited by G. Calin

(c) (i) Open Access This article is licensed under a Creative Commons Attribution 4.0 International License, which permits use, sharing, adaptation, distribution and reproduction in any medium or format, as long as you give appropriate credit to the original author(s) and the source, provide a link to the Creative Commons license, and indicate if changes were made. The images or other third party material in this article are included in the article's Creative Commons license, unless indicated otherwise in a credit line to the material. If material is not included in the article's Creative Commons license and your intended use is not permitted by statutory regulation or exceeds the permitted use, you will need to obtain permission directly from the copyright holder. To view a copy of this license, visit http://creativecommons.org/licenses/by/4.0/. 


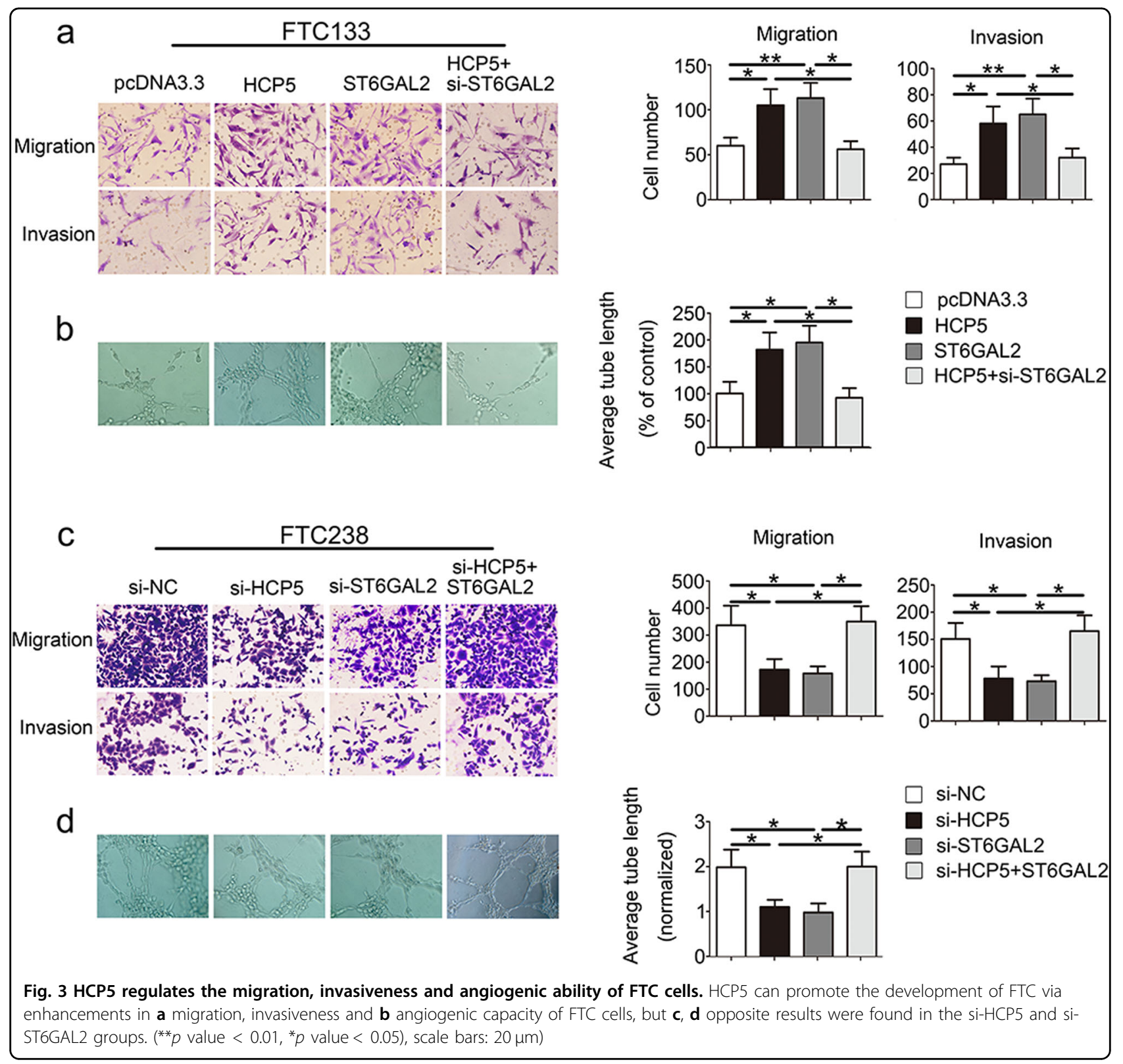

